\title{
Sourcing the iron in the naturally fertilised bloom around the Kerguelen Plateau: particulate trace metal dynamics
}

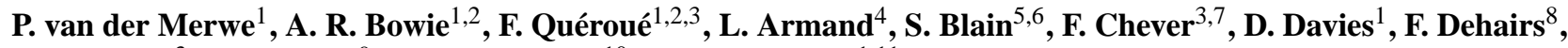 \\ F. Planchon ${ }^{3}$, G. Sarthou ${ }^{9}$, A. T. Townsend ${ }^{10}$, and T. W. Trull ${ }^{1,11}$ \\ ${ }^{1}$ Antarctic Climate and Ecosystems CRC, University of Tasmania, TAS 7004, Australia \\ ${ }^{2}$ Institute for Marine and Antarctic Studies, University of Tasmania, Battery Point, TAS 7004, Australia \\ ${ }^{3}$ Laboratoire des Sciences de l'Environnement Marin (LEMAR), Université de Bretagne Occidentale, CNRS,IRD, \\ UMR6539, IUEM, Technopole Brest Iroise, Place Nicolas Copernic, 29280 Plouzané, France \\ ${ }^{4}$ Department of Biological Sciences and Climate Futures, Macquarie University, North Ryde, NSW 2109, Australia \\ ${ }^{5}$ Sorbonne Universités, UPMC Univ Paris 06, UMR7621, Laboratoire d'Océanographie Microbienne, Observatoire \\ Océanologique, 66650 Banyuls/mer, France \\ ${ }^{6}$ CNRS, UMR7621, Laboratoire d'Océanographie Microbienne, Observatoire Océanologique, 66650 Banyuls/mer, France \\ ${ }^{7}$ IFREMER/Centre de Brest, Département REM/EEP/Laboratoire Environnement Profond, \\ CS 10070, 29280 Plouzané, France \\ ${ }^{8}$ Vrije Universiteit Brussel, Analytical, Environmental and Geo-Chemistry \& Earth System Sciences \\ research group, Brussels, Belgium \\ ${ }^{9}$ CNRS, Université de Brest, IRD, Ifremer, UMR6539 LEMAR, IUEM ; Technopôle Brest Iroise, \\ Place Nicolas Copernic, 29280 Plouzané, France \\ ${ }^{10}$ Central Science Laboratory, University of Tasmania, Sandy Bay, TAS 7005, Australia \\ ${ }^{11}$ Commonwealth Scientific and Industrial Research Organisation, Oceans and Climate Flagship, \\ GPO Box 1538, Hobart, Tasmania, Australia
}

Correspondence to: P. van der Merwe (pvander@utas.edu.au)

Received: 26 August 2014 - Published in Biogeosciences Discuss.: 18 September 2014

Revised: 15 December 2014 - Accepted: 8 January 2015 - Published: 6 February 2015

\begin{abstract}
The KEOPS2 project aims to elucidate the role of natural Fe fertilisation on biogeochemical cycles and ecosystem functioning, including quantifying the sources and processes by which iron is delivered in the vicinity of the Kerguelen Archipelago, Southern Ocean. The KEOPS2 process study used an upstream high-nutrient, low-chlorophyll (HNLC), deep water $(2500 \mathrm{~m})$, reference station to compare with a shallow $(500 \mathrm{~m})$, strongly fertilised plateau station and continued the observations to a downstream, bathymetrically trapped recirculation of the Polar Front where eddies commonly form and persist for hundreds of kilometres into the Southern Ocean. Over the Kerguelen Plateau, mean particulate $(1-53 \mu \mathrm{m}) \mathrm{Fe}$ and $\mathrm{Al}$ concentrations $(\mathrm{pFe}=13.4 \mathrm{nM}$, $\mathrm{pAl}=25.2 \mathrm{nM}$ ) were more than 20-fold higher than at an offshore (lower-productivity) reference station $(\mathrm{pFe}=0.53 \mathrm{nM}$, $\mathrm{pAl}=0.83 \mathrm{nM})$. In comparison, over the plateau dissolved
\end{abstract}

Fe levels were only elevated by a factor of $\sim 2$. Over the Kerguelen Plateau, ratios of $\mathrm{pMn} / \mathrm{pAl}$ and $\mathrm{pFe} / \mathrm{pAl}$ resemble basalt, likely originating from glacial/fluvial inputs into shallow coastal waters. In downstream, offshore deep-waters, higher $\mathrm{pFe} / \mathrm{pAl}$, and $\mathrm{pMn} / \mathrm{pAl}$ ratios were observed, suggesting loss of lithogenic material accompanied by retention of $\mathrm{pFe}$ and $\mathrm{pMn}$. Biological uptake of dissolved Fe and $\mathrm{Mn}$ and conversion into the biogenic particulate fraction or aggregation of particulate metals onto bioaggregates also increased these ratios further in surface waters as the bloom developed within the recirculation structure. While resuspension of shelf sediments is likely to be one of the important mechanisms of Fe fertilisation over the plateau, fluvial and glacial sources appear to be important to areas downstream of the island. Vertical profiles within an offshore recirculation feature associated with the Polar Front show pFe 
and pMn levels that were 6-fold and 3.5-fold lower, respectively, than over the plateau in surface waters, though still 3.6-fold and 1.7-fold higher respectively than the reference station. Within the recirculation feature, strong depletions of $\mathrm{pFe}$ and $\mathrm{pMn}$ were observed in the remnant winter water (temperature-minimum) layer near $175 \mathrm{~m}$, with higher values above and below this depth. The correspondence between the $\mathrm{pFe}$ minima and the winter water temperature minima implies a seasonal cycle is involved in the supply of pFe into the fertilised region. This observed association is indicative of reduced supply in winter, which is counterintuitive if sediment resuspension and entrainment within the mixed layer is the primary fertilising mechanism to the downstream recirculation structure. Therefore, we hypothesise that lateral transport of $\mathrm{pFe}$ from shallow coastal waters is strong in spring, associated with snow melt and increased runoff due to rainfall, drawdown through summer and reduced supply in winter when snowfall and freezing conditions predominate in the Kerguelen region.

\section{Introduction}

Small scale fertilisation experiments have now clearly established that Southern Ocean primary production is limited by the availability of the micronutrient iron (Fe) (Boyd et al., 2007; de Baar, 2005). This limitation on the biological pump means that the Southern Ocean does not realise its full potential in transferring atmospheric $\mathrm{CO}_{2}$ into the ocean interior; a result illustrated in Antarctic continental ice records over geological timescales and supported by modelling studies (Barnola et al., 1987; Bopp et al., 2003; Martin, 1990; Watson et al., 2000). Less well understood is the overall system response to the addition of $\mathrm{Fe}$ as efficiency estimates (defined here as the amount of carbon exported relative to Fe added above baseline conditions) can vary by an order of magnitude (Blain et al., 2007; Pollard et al., 2009; Savoye et al., 2008). Both the original and subsequent KEOPS missions aimed to resolve not only the efficiency estimate, but also the response of the ecosystem and the overall effect on biogeochemical cycles due to natural $\mathrm{Fe}$ fertilisation in the vicinity of the Kerguelen Plateau. The KEOPS natural fertilisation experiment is complementary to artificial $\mathrm{Fe}$ enrichment experiments due to the fact that its scale is much larger and its time frame longer than that which is currently feasible in artificial fertilisation experiments. Furthermore, due to the sustained release of $\mathrm{Fe}$ into the fertilised region, as opposed to a sudden pulse artificial experiment, the technical challenges of monitoring carbon export are reduced. Furthermore, there is growing evidence that sustained Fe fertilisation favours large, highly silicified, slow growing diatoms that are efficient at exporting carbon into the ocean interior (Quéguiner, 2013). When the results of process studies such as KEOPS are extrapolated over the whole Southern Ocean, a small change in the efficiency estimate could result in different conclusions as to the efficacy, for instance, of artificial $\mathrm{Fe}$ fertilisation as a means of mitigating rising atmospheric concentrations of anthropogenic $\mathrm{CO}_{2}$.

Dissolved $\mathrm{Fe}(\mathrm{dFe}<0.2 \mu \mathrm{m})$ includes colloidal and nanoparticulate $\mathrm{Fe}$, which may only be partially bioavailable, as well as soluble $\mathrm{Fe}(\mathrm{sFe}<0.02 \mu \mathrm{m})$ which is highly bioavailable (de Baar and de Jong, 2001). As a result, the larger particulate fraction $(>0.2 \mu \mathrm{m})$ is often less studied due to the perception that it has low bioavailability. However, the particulate fraction can yield important information for several reasons; firstly the dissolved fraction is constantly in a state of change with uptake, particle scavenging and remineralisation occurring simultaneously and at varying rates depending on many factors including complexation with organic ligands (Johnson et al., 1997) and the biological community present (Sunda, 2001). Thus, interpretation of dFe data is difficult without a rarely obtained perspective on the time varying aspects of the dFe distribution. Secondly, as a fraction of the total $\mathrm{Fe}$, the major sources of $\mathrm{Fe}$ into fertilised regions (e.g. weathering products delivered by fluvial and glacial processes, resuspension of sediments and porewaters, atmospheric and extra-terrestrial dust) are small particles $(>0.2 \mu \mathrm{m})$, with the concentration being more stable over weeks to months, due to its abundance and relatively slow biological uptake. The particulate fraction is primarily lost from surface waters through sinking, either directly or via adhesion to bioaggregates (Frew et al., 2006). However, there is a constant transfer of dissolved $\mathrm{Fe}$ to particulate $\mathrm{Fe}$, either via biological uptake or precipitation and, particulate Fe to dissolved Fe, via dissolution and biologically mediated processes (Moffett, 2001). Thus, the particulate fraction that is small enough to avoid sinking out of the water column rapidly $(0.2-5 \mu \mathrm{m})$ can be considered as a significant source of dissolved Fe, with the rate of supply into surrounding waters dependent on the dissolution and leaching rate. Furthermore, there is growing evidence that particles in this size fraction are readily produced by mechanical erosion of bedrock due to glacial processes at high latitudes and that this large source may be partially bioavailable (Hawkings et al., 2014; Poulton and Raiswell, 2005; Raiswell et al., 2008a, b, 2006).

The first KEOPS process study was conducted in 2005 and specifically focused on processes affecting the demise of the spring bloom over the Kerguelen Plateau (Blain et al., 2007). Blain et al. (2007) and Chever et al. (2010) demonstrated that $\mathrm{dFe}$ fertilisation from the plateau increased primary production in the area. From the data gathered it was proposed that resuspension of plateau-derived sediments and entrainment into the mixed layer during increased wind mixing that deepened the mixed layer, was the primary source of particulate and subsequently, dissolved Fe to the downstream blooms. Resolution of the Fe budget (accounting for all sources and sinks of $\mathrm{Fe}$ in the system), from observations made during the first mission, found that the vertical supply of dissolved 


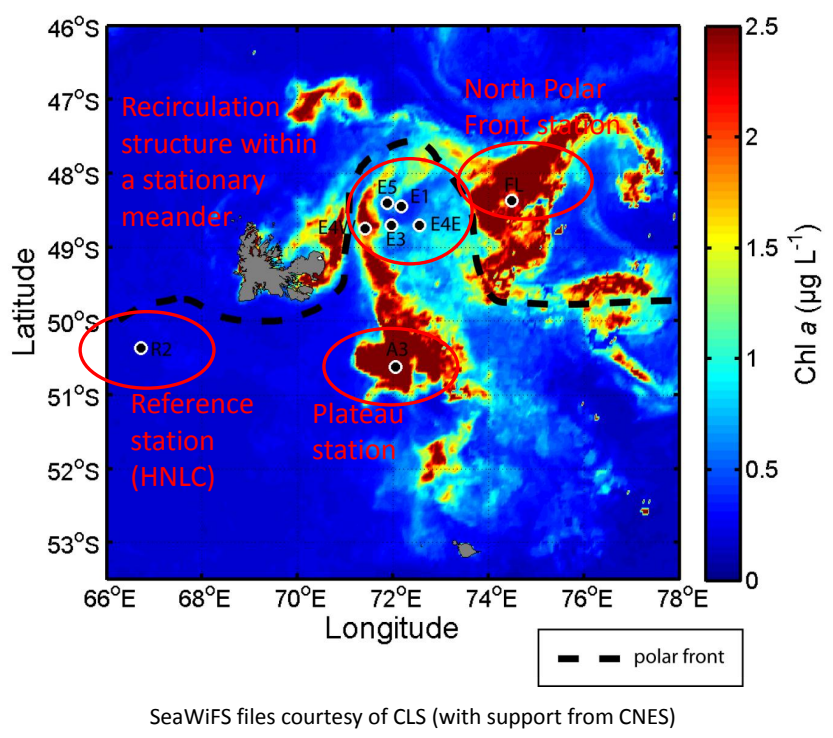

Figure 1. SeaWiFS surface chlorophyll on 11 November 2011, approximately half way through the KEOPS 2 sampling program. Kerguelen and Heard Island are visible in grey. Stations that were sampled for suspended particles are indicated with black circles. Distinct regimes of interest for the KEOPS2 program are indicated in red.

Fe was not sufficient to supply phytoplankton demand. Blain et al. (2007) closed the KEOPS Fe budget by assuming that dissolution of a small fraction of the unconstrained particulate Fe pool must occur. The KEOPS2 mission aimed to improve on the successes of the first process study by accounting for the missing $\mathrm{Fe}$ in the budget, namely particulate $\mathrm{Fe}(\mathrm{pFe})$. Thus, we aim to test the KEOPS1 hypothesis that unconstrained particulate $\mathrm{Fe}$ is the missing $\mathrm{Fe}$ of the KEOPS Fe budget by documenting the particulate metal enrichment around the Kerguelen Plateau. Our goal is to determine the sources of $\mathrm{Fe}$ enrichment within areas of interest (i.e. reference, plateau and the recirculation structure; see Fig. 1). Trace metal analysis of suspended particles, underlying sediment and settling particulate material will elucidate the source to sink progression of the particulate Fe pool. Following on from this work, and together with dissolved $\mathrm{Fe}$ measurements (Quéroué et al., 2015), a focused Fe budget will be constructed (Bowie et al., 2014).

\section{Methods}

\subsection{In situ pumps (ISPs)}

All sample handling, processing and preparation was performed in accordance with general GEOTRACES protocols (http://www.geotraces.org/) and specific methodologies outlined in Bowie et al. (2010). Briefly, suspended particles were collected using up to 11 in situ pumps (ISPs) (McLane WTS and Challenger) suspended simultaneously at varying depths throughout the water column. Depths were chosen after viewing conductivity, temperature and depth (CTD) data to sample within oceanographic features of interest as well as obtaining a representative full water column profile. The ISPs were fitted with $142 \mathrm{~mm}$ quartz micro fibre (QMA) (Sartorius) filters with $53 \mu \mathrm{m}$ Petex pre-filters and $350 \mu \mathrm{m}$ polyester supports. QMA filters were pre-combusted to remove particulate organic carbon and then acid-washed with Seastar Baseline ${ }^{\mathrm{TM}} \mathrm{HCl}$ and rinsed with copious amounts of ultra-pure water according to the methods outlined in the GEOTRACES sample handling protocols handbook (Cutter et al., 2010). The pre-filters and supports were carefully acid washed and rinsed with copious amounts of ultra-pure water before use. Both the Petex pre-filter and QMA filter were analysed for every pump giving two size fractions at each sampling location. Therefore, all particles greater than $53 \mu \mathrm{m}$ were collected on the pre-filter and all particles within the $1-53 \mu \mathrm{m}$ size range were collected on the underlying QMA filter. Lithogenics sourced from bedrock or sediments in the larger size range $(>53 \mu \mathrm{m})$ would have a high sinking velocity (>500 $\mathrm{m} \mathrm{day}^{-1}$ ) according to Stokes' law and as such would be expected to make up a relatively small fraction of the total particles in this size range. In comparison, the 1$53 \mu \mathrm{m}$ size class can potentially capture both small biogenic and lithogenic particles. This is due to the prediction that small lithogenic particles $(1-5 \mu \mathrm{m})$ have significantly slower sinking rates $\left(0.1-10 \mathrm{~m} \mathrm{day}^{-1}\right)$ than large lithogenic particles according to Stokes' law.

The ISPs were programmed to pump for up to four hours, allowing up to $2000 \mathrm{~L}$ of seawater to be filtered. After retrieval, the filters were bagged and processed within an ISO class 5 , containerised clean room. Replicate $14 \mathrm{~mm}$ punches were taken using an acid-washed polycarbonate punch and stored frozen at $-18{ }^{\circ} \mathrm{C}$ until analysis at the home laboratory. The $14 \mathrm{~mm}$ punches were then used for particulate metal analysis, particulate organic carbon and particulate organic nitrogen analysis.

\subsection{Sediment traps (Technicap PPS3)}

For a full description of the sediment trap data during KEOPS2 see Laurenceau et al. (2014) and Bowie et al. (2014). Two Technicap PPS3 free-floating sediment traps were deployed below the mixed layer at a depth of $200 \mathrm{~m}$. The two sediment traps were deployed twice, giving a total of four deployments. The traps were prepared with acidcleaned sampling cups containing low-trace-metal brine solution (salinity $\sim 60$ ). The trap was programmed to sample for 1.5-5.5 days, whilst the 12 individual sampling containers were open for an equal portion of the total deployment. Upon retrieval, the sampling containers were removed from the carousel, sealed and processed within an ISO class 5, containerised clean room. The samples were filtered onto acidwashed, $2 \mu \mathrm{m}$ polycarbonate membrane filters via a $350 \mu \mathrm{m}$ pre-filter using a Sartorius ${ }^{\text {TM }}$ PTFE filtration unit. The $350 \mu \mathrm{m}$ 
pre-filter was selected to exclude large copepods and other large plankton that would lead to unrealistic sample variability.

\subsection{Sediment coring}

An Oktopus Multicorer (www.oktopus-mari-tech.de) was used to collect 8 replicate, $610 \times 95 \mathrm{~mm}$ sediment cores, simultaneously within a $1 \mathrm{~m}^{2}$ area at each station. The uppermost $5 \mathrm{~mm}$ of surface sediment was subsampled according to Armand et al. (2008) representing an approximate sedimentation period of $<1000$ years.

\subsection{Analysis}

\subsubsection{ISP filters for particulate metals}

All digestions and evaporations were carried out within a digestion hood (SCP Science), where air was HEPA filtered during intake and subsequently extracted through a fume hood. Filter blanks and sample filters were digested in $15 \mathrm{~mL}$ acid cleaned, Teflon perfluoroalkoxy (PFA) screw cap vials (Savillex ${ }^{\mathrm{TM}}$ ) using ultra-pure nitric acid (1 $\mathrm{mL} 16 \mathrm{M} \mathrm{HNO}_{3}$ ) (Seastar Baseline ${ }^{\mathrm{TM}}$ ) heated to $120^{\circ} \mathrm{C}$ for $12 \mathrm{~h}$ on a Teflon coated hotplate (SCP Science DigiPREP ${ }^{\mathrm{TM}}$ ), following the method outlined in Bowie et al. (2010). Blanks containing only $\mathrm{HNO}_{3}$ were also analysed to determine the contribution of the digestion acid without filter material.

The digest solution was diluted with $9 \mathrm{~mL}$ of ultra-high purity water and spiked to a final concentration of $10 \mathrm{ppb}$ indium as an internal standard. Samples were analysed by Sector Field ICP-MS (Finnigan Element II, Thermo Scientific) (Cullen and Sherrell, 1999; Townsend, 2000). A full suite of trace elements was measured including $\mathrm{Fe}, \mathrm{Al}, \mathrm{Mn}, \mathrm{Ba}$ and $\mathrm{P}$. The data were quality controlled by comparison with a certified reference material with a similar composition to the material collected (BCR-414 trace metals in phytoplankton, European Commission) (Table A1).

Quartz micro-fibre (QMA) filters were chosen as they could be acid cleaned to a trace-metal-clean level and the filter material allowed high particle loading and low washoff upon pump retrieval. Furthermore, the filters were compatible for use with both Inductively Coupled Plasma Mass Spectrometry (ICP-MS) and elemental (CHN) analysis due to their ability to be combusted. It should be noted that a compromise was made here by using QMA filters on the ISPs. The compromise is that HF acid cannot be used with QMA filters as it digests the filter material completely and leads to unacceptably high analytical blanks. Therefore, we used $\mathrm{HNO}_{3}$ for the digestions of the QMAs and for consistency regarding the suspended particles we also digested the pre-filter with the same acid. On the other hand, we used a full $\mathrm{HF}$ acid digestion for the underlying sediment analysis (Sect. 2.4.2). Therefore, recoveries of lithogenic trace elements will be close to $100 \%$ for the sediment analysis, but somewhat lower for the lithogenic suspended particles. However, a $\mathrm{HNO}_{3}$ only digestion will recover effectively $100 \%$ of the trace elements of biogenic suspended particles (Table A1). For further information see Bowie et al. (2010).

\subsubsection{Sediment analysis for particulate metals}

Digestions and analysis were performed as per the ISP filters except that HF acid was used to digest these highly refractory samples. The $\mathrm{HNO}_{3}$ digest used for the ISP filters is relatively weak but digests the biogenic fraction completely as evidenced by the excellent recoveries on the BCR414 certified reference material (trace metals in phytoplankton) (Table A1) but has limited recoveries of the lithogenic fraction as evidenced by the low recoveries of pAl and pTi in MESS3 and PACS-2 sediment certified reference material (Bowie et al., 2010).

During the HF digest, a mixture of strong acids $(250 \mu \mathrm{L}$ $\mathrm{HNO}_{3}, 250 \mu \mathrm{L} \mathrm{HF}$ and $500 \mu \mathrm{L} \mathrm{HCl}$ ) were used as per Bowie et al. (Bowie et al., 2010). After $12 \mathrm{~h}$ at $95^{\circ} \mathrm{C}$ the digest PFA vials were uncapped and evaporated to dryness under HEPA filtered air at $60^{\circ} \mathrm{C}$ for $4 \mathrm{~h}$. The digest was then resuspended in $10 \% \mathrm{HNO}_{3}$ with $10 \mathrm{ppb}$ indium as internal standard. A $100 \times$ dilution factor $(v: v)$ was considered sufficient to place the $\sim 20 \mathrm{mg}$ sediment samples within the calibration range of the SF-ICP-MS.

\subsubsection{Particulate organic carbon (POC) and nitrogen (PN)}

All glassware in contact with POC samples was precombusted prior to field work $\left(450^{\circ} \mathrm{C}\right.$ for $\left.12 \mathrm{~h}\right)$. Total nitrogen, carbon and hydrogen were determined at the Central Science Laboratory, University of Tasmania, using a Thermo Finnigan EA 1112 Series Flash Elemental Analyzer (estimated precision $\sim 1 \%$ ).

\section{Results and discussion}

\subsection{Station types}

The sampling locations of KEOPS2 (Fig. 1) were designed to capture the key regime types of the Kerguelen Archipelago including the high-nutrient, low-chlorophyll (HNLC) reference waters (station R-2), the high-trace-metal plateau waters (station A3), the northern Polar Front (station F-L) and a quasi-stationary, bathymetrically trapped recirculation structure (E-1, E-3 and E-5) to the east of Kerguelen Island (Table 1). Stations E-1, E-3 and E-5 can be thought of as a pseudo-Lagrangian time series. In addition, two stations were sampled at the eastern and western extremes of the recirculation structure (E-4W and E-4E) which proved to contrast in absolute concentrations as well as elemental ratios of particulate trace metals. 
Table 1. KEOPS2 sampling locations and station types.

\begin{tabular}{|c|c|c|c|c|c|c|c|c|c|}
\hline & A3-1 & A3-2 & $\mathrm{R}-2$ & F-L & E-1 & E-3 & E-5 & E-4E & E-4W \\
\hline Station type & Kerguelen & Kerguelen & HNLC reference & Northern & Recirculation & Recirculation & Recirculation & Eastern recirculation & Western recirculation \\
\hline Sampling date & $\begin{array}{r}\text { Plateau 1st visit } \\
20 / 10 / 2011\end{array}$ & $\begin{array}{r}\text { Plateau 2nd visit } \\
16 / 11 / 2011\end{array}$ & $\begin{array}{r}\text { station } \\
25 / 10 / 2011\end{array}$ & $\begin{array}{r}\text { Polar Front } \\
6 / 11 / 2011\end{array}$ & $\begin{array}{r}\text { structure } \\
29 / 10 / 2011\end{array}$ & $\begin{array}{r}\text { structure } \\
3 / 11 / 2011\end{array}$ & $\begin{array}{r}\text { structure } \\
18 / 11 / 2011\end{array}$ & $\begin{array}{r}\text { structure } \\
13 / 11 / 2011\end{array}$ & $\begin{array}{r}\text { structure } \\
11 / 11 / 2011\end{array}$ \\
\hline Latitude (S) & $50^{\circ} 37.7574^{\prime}$ & $50^{\circ} 37.4306^{\prime}$ & $50^{\circ} 21.52^{\prime}$ & $48^{\circ} 31.394^{\prime}$ & $48^{\circ} 29.5728^{\prime}$ & $48^{\circ} 42.1334^{\prime}$ & $48^{\circ} 24.698^{\prime}$ & $48^{\circ} 42.9218^{\prime}$ & $48^{\circ} 45.927^{\prime}$ \\
\hline Longitude (E) & $72^{\circ} 4.8193^{\prime}$ & $72^{\circ} 3.3366^{\prime}$ & $66^{\circ} 43.00^{\prime}$ & $74^{\circ} 40.036^{\prime}$ & $72^{\circ} 14.1467^{\prime}$ & $71^{\circ} 58.0027^{\prime}$ & $71^{\circ} 53.7894^{\prime}$ & $72^{\circ} 33.7792^{\prime}$ & $71^{\circ} 25.51^{\prime}$ \\
\hline Bottom depth (m) & 505 & 505 & 2528 & 2690 & 2050 & 1910 & 1920 & 2200 & 1400 \\
\hline Time series & Yes & Yes & No & No & Yes & Yes & Yes & No & No \\
\hline Particulate trace metals & Yes & Yes & Yes & Yes & Yes & Yes & Yes & Yes & Yes \\
\hline POC PON & Yes & Yes & Yes & Yes & Yes & Yes & Yes & Yes & Yes \\
\hline Sediment samples & Yes & Yes & Yes & Yes & No & Yes & No & No & Yes \\
\hline Sediment trap samples & No & Yes & No & No & Yes & Yes & Yes & No & No \\
\hline
\end{tabular}

SPRING - SUMMER
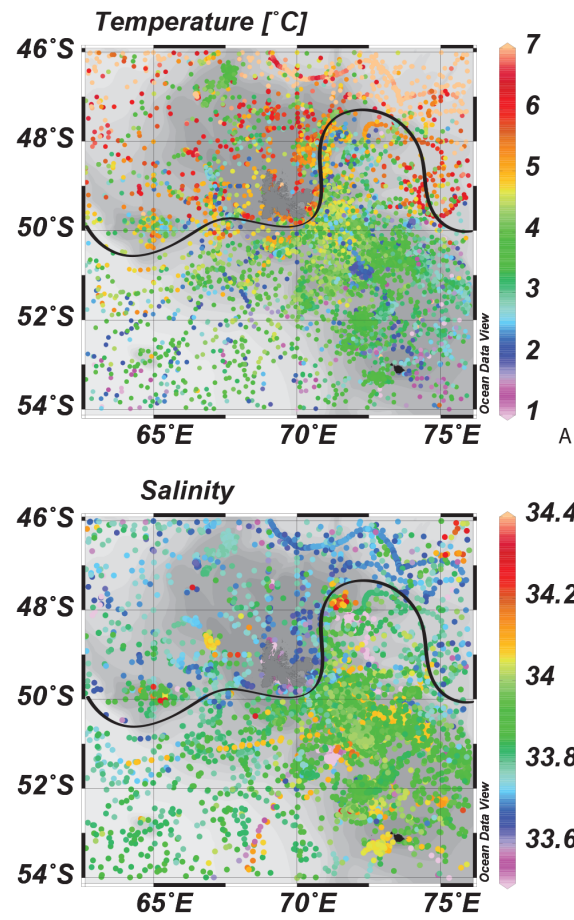

AUTUMN - WINTER
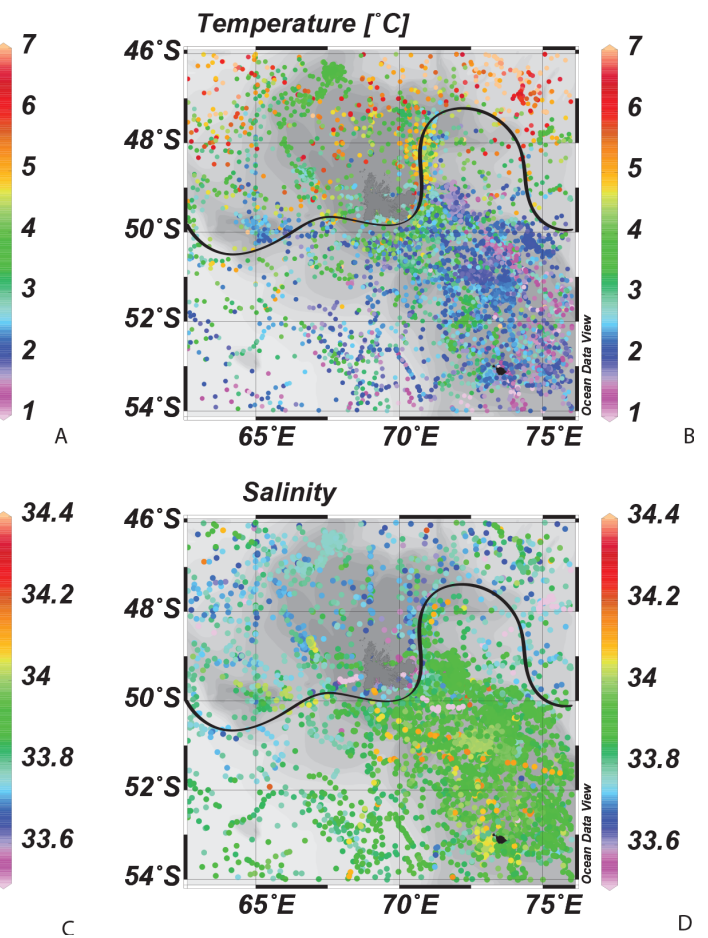

Figure 2. Surface $(10 \mathrm{~m})$ temperature in spring-summer (a) and autumn-winter (b) as well as surface salinity in spring-summer (c) and autumn-winter (d) within the study area from 1970 until 2013. The PF is identified as a solid black line. Kerguelen and Heard Island are visible in dark grey and black respectively and the Leclaire Rise can be identified as the shallow bathymetry, north of the PF, near the western boundary of the map. Data obtained from the World Ocean Database (http://www.nodc.noaa.gov).

\subsection{Surface water flow around the Kerguelen Plateau}

During KEOPS1, van Beek et al. (2008), Zhang et al. (2008) and Chever et al. (2010) revealed that the water column south-east of Kerguelen Island was modified by passing over the Heard Island Plateau. Park et al. (2008) demonstrated that the interaction of the water masses over the Kerguelen Plateau could be divided into the southern and northern water masses separated by the Polar Front (PF, Fig. 1). The southern water mass has source waters being derived from the Antarctic surface waters (AASW), south-west of Kerguelen which is bound to the north by the shallow bathymetry of the Leclaire Rise. These surface waters are generally colder and saltier than to the north (Fig. 2). The AASW also flows around Heard Island and a weaker surface current flows north-west over the Kerguelen Plateau towards the north-east of Kerguelen Island where it is bound to the north by the PF. This cold surface current can be seen during winter in Fig. 2. The northern water mass has a source of easterly flowing Sub Antarctic Surface Waters (SASW). The portion of the SASW that interacts with Kerguelen Island is termed Kerguelen Island source waters and is bound to the south by the PF (Fig. 2). A broad and poorly defined mixing zone to the east of Kerguelen Island has been identified at the junction of 
these southern and northern water masses. As a result of the mixing, eddies commonly form in this region. Also within this mixing zone, surface filaments, identified by elevated Chlorophyll $a$, can be seen in SeaWiFS images diverging from the PF and entering the eastern boundary of the recirculation structure (see the Supplement in Trull et al., 2014).

The Kerguelen Archipelago is isolated, being a relatively small and localised source of Fe fertilisation surrounded by the large and deep, HNLC, low Fe, Southern Ocean. Therefore, when identifying an Fe source to the region, our focus is on the plateau and the two islands, Kerguelen and Heard. Over geological timescales, all $\mathrm{pFe}$ distributed throughout the water column within this region must be derived from all forms of weathering of bed rock including fluvial and glacial outflow as well as dust from the islands, hydrothermal and extra-terrestrial input. Over shorter time frames, shelf sediments in the region contain recycled $\mathrm{Fe}$ as the vast majority of these sediments are a combination of siliceous ooze (Armand et al., 2008) and glacio-marine sediments; the exported product of the highly productive overlying waters together with some lithogenics (sourced from bed-rock) that were unutilised or non-bioavailable and fast-sinking. Therefore, understanding the pathways of supply of this new $\mathrm{Fe}$ is important to understanding the processes controlling the long term productivity and therefore, carbon sequestration, in the area.

\subsection{Underlying sediment analysis}

Analysis of sediments sourced from cores taken at each station revealed a distinctly different sediment signature at station R-2 compared with any other station (Table 2). The reference station signature was approximately six times enriched in $\mathrm{Mn}$ relative to $\mathrm{Al}(\mathrm{Mn}: \mathrm{Al}$ 0.063) in comparison to the plateau station (A3) (Mn: $\mathrm{Al} 0.011)$. The $\mathrm{Mn}: \mathrm{Al}$ sedimentary signature at A3 was almost identical to authigenic sediments previously reported from the Amundsen Sea (Angino, 1966). We consider that the enriched Mn at R-2 could be due to either $\mathrm{MnO}_{2}$ enrichment in the surface sediments during redox cycling of early diagenesis (Planquette et al., 2013), or supplied via a Mn enriched source such as hydrothermal venting near the Leclaire Rise. The extremely low carbon content of the sediment at station R-2, as evidenced by its near white colour, low diatom content (L. Armand, pers. obs., 2012) and low carbon export flux (Laurenceau et al., 2014; Planchon et al., 2014), suggests that $\mathrm{MnO}_{2}$ enrichment in the surface sediments during redox cycling is more likely at R-2.

The authigenic sediment ratio of $\mathrm{Fe}: \mathrm{Al}$ was also lower at station $\mathrm{R}-2(\mathrm{Fe}: \mathrm{Al}=0.73)$ in comparison to any other station (Fe : $\mathrm{Al}$ range $0.81-1.1$ ). However, all of our observed $\mathrm{pFe}$ : pAl molar ratios were higher than upper crustal molar ratios (Fe : Al 0.19) (Wedepohl, 1995) or Amundsen Sea surface sediments (Fe: Al 0.26) (Angino, 1966). Interestingly, our observed $\mathrm{pFe}: \mathrm{pAl}$ sedimentary ratios were sim- ilar to the ratio found in phytoplankton such as the BCR414 certified reference material (freshwater phytoplankton) $(\mathrm{Fe}: \mathrm{Al}=1.01$ ) used in this study (Table $\mathrm{A} 1)$. Furthermore, the $\mathrm{pFe}: \mathrm{pAl}$ ratio of sinking particles captured by the free floating PPS3 sediment traps (marine snow) had similar ratios of $\mathrm{pFe}: \mathrm{pAl}$ of $1.02,1.05,0.91$ and 0.70 for stations $\mathrm{E}-$ 1, E-3, E-5 and A3-2, respectively (Table 2). These observations highlight the major contribution of sinking biogenic material to the authigenic sediments in the area around the Kerguelen Plateau which was in contrast to the signature at station R-2 due to its low productivity. The $\mathrm{pFe}$ in the sediments at all stations and primarily at station R-2 (as a fraction of its total weight) were similar to Weddell Sea surface sediments (Angino and Andrews, 1968) which ranged from 0.9$3.2 \%$. In comparison, station R-2 has a mean value of $0.1 \%$ Fe while station E-3, A3, F-L and E-4W had mean values of $0.3,0.8,1.5$ and $2.5 \%$ respectively. The low fraction of $\mathrm{Fe}$ within the authigenic sediment at R-2 indicates limited $\mathrm{pFe}$ supply at this station in comparison to either the Weddell Sea or the Kerguelen Plateau presented here.

\subsection{Plateau, reference and Polar Front stations}

The reference station (R-2) has a bottom depth of $2528 \mathrm{~m}$ and is characterised by low surface $\mathrm{Chl} a$ concentrations (Lasbleiz et al., 2014) and nutrient concentrations characteristic of HNLC waters (Blain et al., 2014). Station F-L is approximately $313 \mathrm{~km}$ northeast of Kerguelen Island with a bottom depth of $2690 \mathrm{~m}$ and represents the northern PF. Station F$\mathrm{L}$ is downstream of Kerguelen Island, with the PF delivering waters that originated near station R-2. In this case, the waters crossing Station F-L have interacted with both the plateau and shallow coastal waters of Kerguelen Island. In contrast, station A3 is located over the Kerguelen Plateau and has a bottom depth of $527 \mathrm{~m}$, making it the shallowest station sampled for trace metal analysis of suspended particles and one of the most likely to be influenced by resuspension of shelf sediments (Fig. 1). The proximity of the station to Heard and Kerguelen Island (roughly half way between the two) means that fluvial and glacial runoff may also drive fertilisation at this site. However, the hydrography of the area dictates that waters which previously interacted with upstream Heard Island are a more likely source to A3 than downstream Kerguelen Island (Park et al., 2008).

The $\mathrm{pFe}, \mathrm{pAl}$ and $\mathrm{pMn}$ concentrations at the reference station (R-2) only increase slightly towards the sea floor; however, enrichment in $\mathrm{pFe}, \mathrm{pAl}$ and primarily $\mathrm{pMn}$ is evident at $500 \mathrm{~m}$ likely due to proximity to the Leclaire Rise (Fig. 3) (discussed in detail below). The northern PF station (F-L) exhibits moderate concentrations of $\mathrm{pFe}, \mathrm{pAl}$ and $\mathrm{pMn}$ throughout the water column, somewhat higher than the reference station, and much higher concentrations are observed in close proximity to the sea floor. It should be noted that the deepest sample at R-2 was $148 \mathrm{~m}$ above the seafloor, while at F$\mathrm{L}$ it was only $90 \mathrm{~m}$ above the sea floor and this could well 
Table 2. Mean elemental molar ratios of marine snow particles captured in free-floating sediment traps, particulate matter (1-53 $\mu$ m) below the mixed layer and authigenic sediments at each station. Note that station TEW-1 is a near-coastal station located within Hillsborough Bay, Kerguelen Island. Station TEW-1 is not discussed in detail in the MS as no samples were collected for suspended particles; however, details are included here to show the influence of close proximity to the island and fluvial/glacial sources.

\begin{tabular}{lrrrr}
\hline Sediment trap @ 210 m & $\mathrm{pFe}: \mathrm{pAl}$ & $\mathrm{pMn}: \mathrm{pAl}$ & $\mathrm{pMn}: \mathrm{pFe}$ & $\mathrm{pBa}: \mathrm{pAl}$ \\
\hline A3-2 & 0.70 & 0.008 & 0.011 & 0.025 \\
E-1 & 1.02 & 0.009 & 0.009 & 0.162 \\
E-3 & 1.05 & 0.010 & 0.010 & 0.285 \\
E-5 & 0.91 & 0.008 & 0.009 & 0.318 \\
\hline Suspended particles mean (> MLD) & & & & \\
\hline A3-1 & 0.53 & 0.007 & 0.013 & 0.027 \\
A3-2 & 0.63 & 0.009 & 0.014 & 0.034 \\
R-2 & 0.65 & 0.036 & 0.059 & 0.322 \\
F-L & 0.77 & 0.020 & 0.027 & 0.190 \\
E-4E & 0.86 & 0.037 & 0.045 & 0.383 \\
E-4W & 0.63 & 0.014 & 0.021 & 0.078 \\
E-1 & 0.68 & 0.023 & 0.034 & 0.185 \\
E-3 & 0.71 & 0.024 & 0.033 & 0.258 \\
E-5 & 0.68 & 0.020 & 0.030 & 0.260 \\
\hline Sediment analysis & & & & \\
\hline TEW-1 & & & & \\
A3-1 & 1.10 & 0.013 & 0.012 & 0.003 \\
R-2 & 0.87 & 0.011 & 0.013 & 0.026 \\
F-L & 0.73 & 0.063 & 0.086 & 0.892 \\
E-4W & 0.82 & 0.016 & 0.019 & 0.040 \\
E-3 & 0.81 & 0.013 & 0.016 & 0.013 \\
Kerguelen Archipelago & 0.93 & 0.015 & 0.016 & 0.125 \\
Basalt mean & & & & $0.002-0.004$ \\
(Gautier et al., 1990) & 0.49 & $0.004-0.010$ & $0.021-0.050$ & \\
Upper continental crust & & & & \\
(Wedepohl, 1995) & & 0.003 & 0.017 & 0.002 \\
\hline & & & & \\
\hline
\end{tabular}

explain the observed difference, given the strong decrease of nepheloid layers away from the seabed (Blain et al., 2007; Jouandet et al., 2014).

Profiles of $\mathrm{pFe}$ and $\mathrm{pAl}$ in the $1-53 \mu \mathrm{m}$ size range from station R-2, A3 and F-L are shown in Fig. 3. The plateau station (A3) was sampled twice during the study (A3-1 and A3-2), separated by 20 days. Surface chlorophyll images revealed that between visits to the site, a large bloom developed in the vicinity and extended over the site, and was beginning to fade again by the time of the second sampling (Trull et al., 2014). Thus, station A3-1 can be thought of as pre-bloom and A3-2 as post-bloom conditions. Particulate $\mathrm{Fe}, \mathrm{Al}$ and $\mathrm{Mn}$ generally increased towards the sea floor at station A3, with the exception of a slight enrichment below the mixed layer during the second visit (A3-2) to the station in the $>53 \mu \mathrm{m}$ size fraction (Fig. 4). To investigate the progression of $\mathrm{pFe}$ through time, we integrated the $\mathrm{pFe}$ throughout the full water column, and observed a decrease in the pFe stock from 9.1 to $4.5 \mathrm{mmol} \mathrm{m}^{-2}$ between the first and second visit to station A3. This translates to a $51 \%$ reduction in $\mathrm{pFe}$ for all size classes combined (i.e. $>1 \mu \mathrm{m}$ ). However, if we look closer at the $\mathrm{pFe}$ distribution only within the surface mixed layer $(165 \mathrm{~m})$ between A3-1 and A3-2, we observe a loss of $70 \%$ of the integrated total $\mathrm{pFe}(>1 \mu \mathrm{m})$ (Fig. 4). Concurrently, using an Underwater Vision Profiler to track particle size distribution, Jouandet et al. (2014) noted a four-fold increase in particle numerical abundance through the full water column. Their one dimensional particle dynamic model supported the hypothesis that the increase in biogenic particles, due to blooming conditions, resulted in the rapid formation of large particles due to coagulation and subsequent vertical transport to the base of the mixed layer. This result is supported in the current data set, in that we see a large decrease in small $\mathrm{pFe}$ particles within the mixed layer and a moderate increase in large $\mathrm{pFe}$ particles at the base of the mixed layer when comparing pre (A3-1) to post (A3-2) bloom conditions (Fig. 4). Furthermore, we observed an increase in biogenic pFe within the surface mixed layer between A3-1 and A3-2 (Sect. 3.7). 

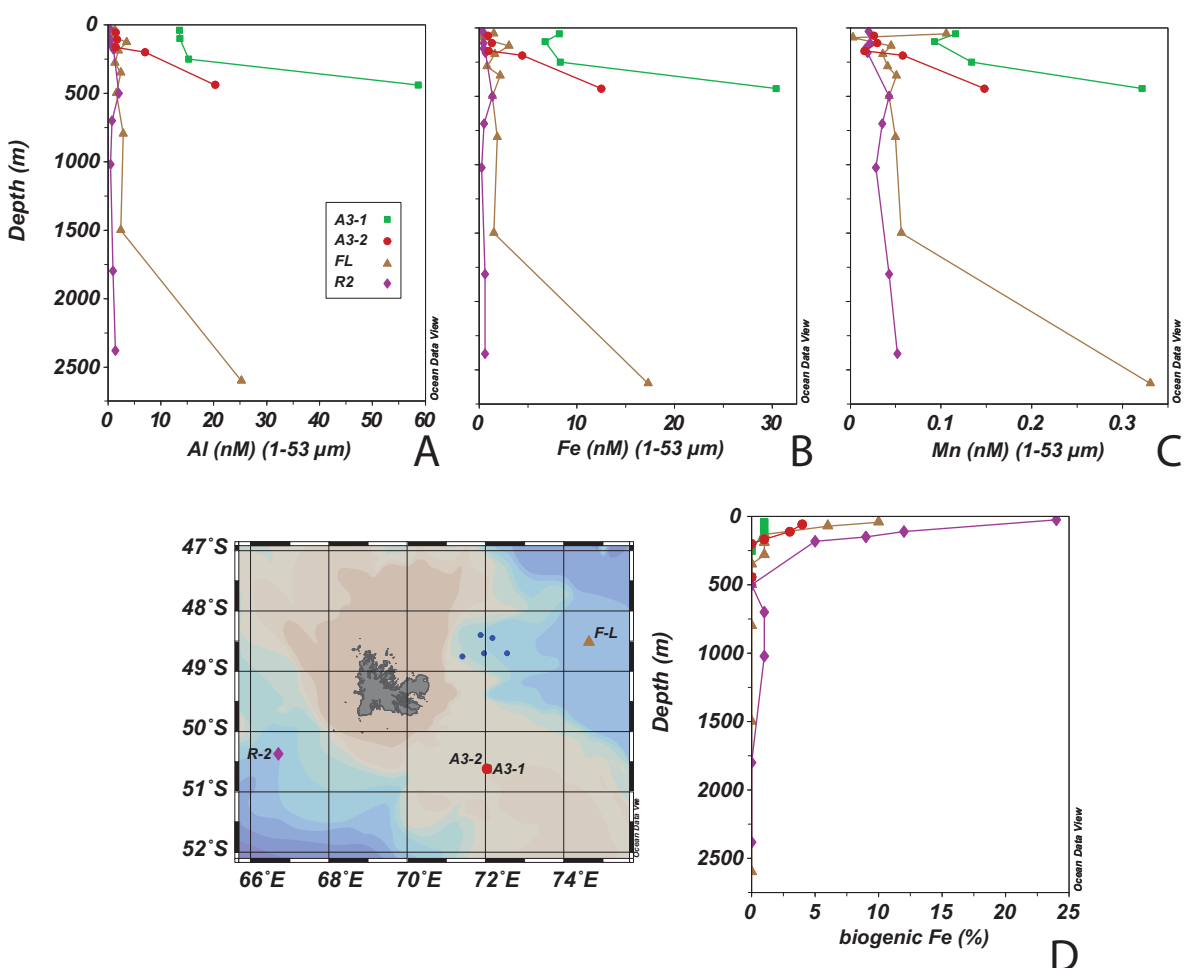

Figure 3. Profiles of particulate $\mathrm{Fe}(\mathbf{a}), \mathrm{Al}(\mathbf{b})$ and $\mathrm{Mn}(\mathbf{c})(1-53 \mu \mathrm{m})$ at the reference HNLC station (R-2), the northern PF station (F-L) and pre- and post-bloom over the plateau station (A3-1, A3-2), highlighting the contrasting particulate trace metal supply to these locations. Biogenic $\mathrm{Fe}$ (d) (as a percentage of the total $\mathrm{Fe}$ ) in surface waters shows a clear progression that can be explained by the location of each station within the study area whereby, biogenic Fe at R-2 >> F-L > A3-2 > A3-1.
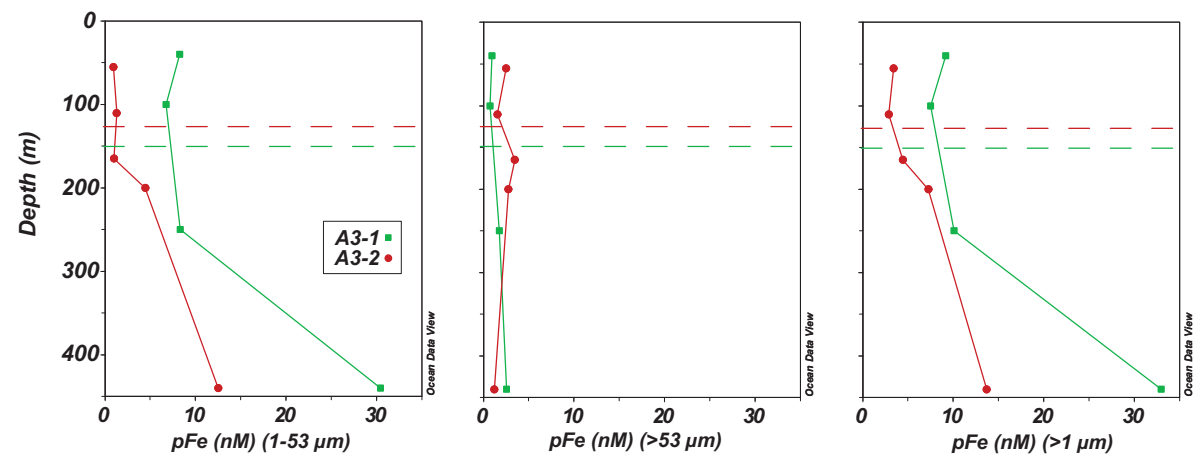

Figure 4. Particulate Fe at the plateau station (A3) by size class. The integrated full water column pFe (>1 $\mu \mathrm{m})$ reduced by $51 \%$ between A3-1 and A3-2 (9.1-4.5 mMol m ${ }^{-2}$ at A3-1 and A3-2 respectively). The integrated mixed layer pFe reduced by $70 \%$ between A3-1 and A3-2 (1.4-0.56 mMol m ${ }^{-2}$ at A3-1 and A3-2 respectively). The mixed layer shoaled between A3-1 and A3-2 as illustrated by the dashed horizontal line. The calculation of integrated mixed layer pFe used a constant mixed layer depth of 165 m for both A3-1 and A3-2 to allow comparison between these stations.

Thus, it appears that physical aggregation within the mixed layer of the particles onto biogenic phyto-aggregates during the bloom development and export to the base of the mixed layer, combined with significantly lower concentrations above the seafloor resulted in the observed $51 \%$ reduction in $\mathrm{pFe}(>1 \mu \mathrm{m})$ between A3-1 and A3-2. The significantly lower concentration at $440 \mathrm{~m}$ during the post-bloom conditions of A3-2 may be due to increased small particle scavenging resulting from sinking phyto-aggregates or alternatively, small-scale variation in the thickness of the nepheloid layer. 

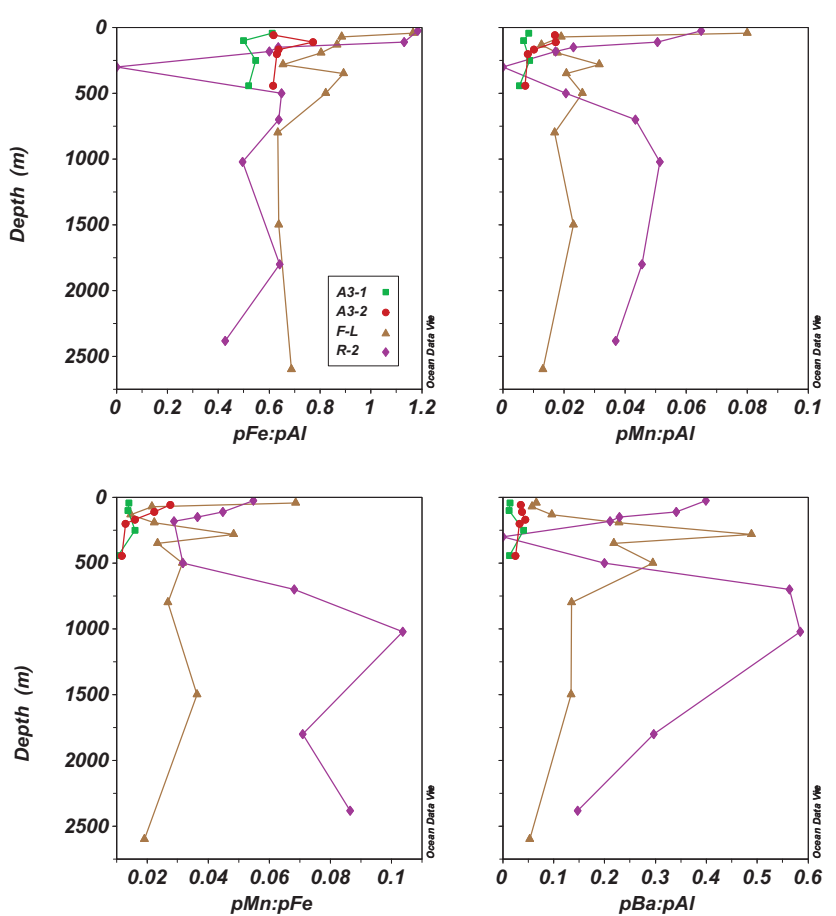

Figure 5. Profiles of elemental ratios at the reference station (R-2), northern PF (F-L) and pre- and post-bloom over the plateau station (A3-1, A3-2). Note the increase in $\mathrm{pMn}$ and $\mathrm{pBa}$ relative to $\mathrm{pAl}$ at station R-2 below $500 \mathrm{~m}$.

\subsection{Elemental ratios at stations R-2, F-L and A3}

As station A3 is located over the Kerguelen Plateau and also is in close proximity to fluvial and glacial runoff from Heard Island, we would expect the trace metal source signature of suspended particles to be unique here in comparison to our reference (R-2) and PF (F-L) stations. The particles over the Kerguelen Plateau were characterised by very high $\mathrm{pFe}(0.94-30.4 \mathrm{nM})$ and $\mathrm{pAl}(1.5-58.6 \mathrm{nM})$ with concentrations an order of magnitude higher than R-2 $(<\mathrm{DL}-1.35 \mathrm{nM}$ $\mathrm{Fe}$ and $<\mathrm{DL}-2.08 \mathrm{nM} \mathrm{Al})$. The reference station was characterised by low surface $\mathrm{Chl} a$ concentrations characteristic of HNLC waters (Lasbleiz et al., 2014), however, it is relatively close to the Leclaire Rise; a seamount with its shallowest point $135 \mathrm{~km}$ west north-west of station R-2 rising up to approximately $395 \mathrm{~m}$. The Leclaire Rise extends to $70 \mathrm{~km}$ north-west of station R-2 where it reaches a depth of approximately $550 \mathrm{~m}$. It is important to recall in this context that the PF divides the northeast flowing AASW from the eastward flowing SASW to the north (Park et al., 2008). Classical theory suggests that this oceanographic feature should block much of the enrichment from the Leclaire Rise to station R2. However, enrichment was evident in the vertical profiles of pFe, pMn and pAl at station R-2 at $500 \mathrm{~m}$ depth (Fig. 3).

Figure 5 illustrates the full water column elemental ratios at the reference station (R-2) in comparison to the Kerguelen Plateau stations (A3-1 and A3-2) and reveals that $\mathrm{Mn}: \mathrm{Fe}$

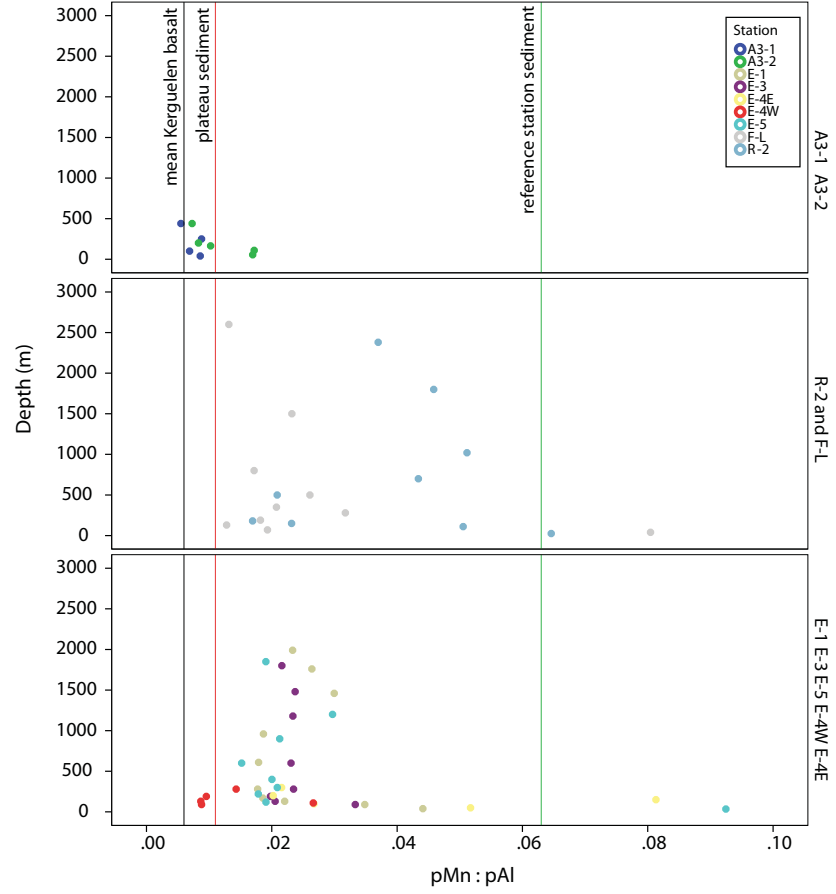

Figure 6. Molar ratio of $\mathrm{pMn}: \mathrm{pAl}$ of suspended particles versus depth, separated by station type. Vertical lines represent the median molar ratios within Kerguelen Island basalts (Gautier et al., 1990) (black), authigenic Kerguelen Plateau sediments (red) and station R-2 authigenic sediments (green).

as well as $\mathrm{Ba}: \mathrm{Al}$ are strikingly unique. At station $\mathrm{R}-2$, below $500 \mathrm{~m}$, we see $\mathrm{Mn}: \mathrm{Fe} 2 \times$ higher than $\mathrm{A} 3, \mathrm{Mn}: \mathrm{Al} 4.5 \times$ higher and $\mathrm{Ba}: \mathrm{Al}$ ratios $10 \times$ higher than at $\mathrm{A} 3$, making this source signature relatively clear (Table 2 ). The unique ratios below $500 \mathrm{~m}$ at R-2 may arise from a source of dissolved or particulate $\mathrm{Mn}$ (uncoupled from $\mathrm{pFe}$ and $\mathrm{pAl}$ ) from the Leclaire Rise. Furthermore, the elemental ratios over station A3 are generally much lower (Fig. 5) due to high pFe and pAl supply over the Kerguelen Plateau that is relatively deficient in $\mathrm{pMn}$, such as would be found in glacial runoff that has a signature which reflects fresh weathering of basaltic rocks (Doucet et al., 2005). This source theory is supported by the observation of high dissolved Mn (dMn) near the Leclaire Rise (Quéroué et al., 2015) and uniquely high $\mathrm{pMn}$ : $\mathrm{pFe}$ in sediments found below station R-2 (Table 2). Surface water particulate trace metals also reveal distinct differences. The ratios of $\mathrm{pFe}: \mathrm{pAl}, \mathrm{pMn}: \mathrm{pAl}$ and $\mathrm{pMn}: \mathrm{pFe}$ all increase from the bottom of the mixed layer to the surface at stations R-2 and F-L (Fig. 5). This profile characteristic is in contrast to stations A3-1. The observed modification of the elemental ratios in the surface mixed layer at R-2 and F-L is most likely due to biological uptake of dissolved trace elements and conversion into the biogenic particulate fraction.

Particulate $\mathrm{Al}$ and $\mathrm{pFe}$ were closely coupled across all stations (Spearman's $\rho R=0.91 P<0.01 n=70$ ). However, $\mathrm{pAl}$ and $\mathrm{pMn}$, although still strongly correlated $(P=0.80$ 
$P<0.01 n=70$ ), appeared more variable than $\mathrm{pFe}$ versus pAl. Figure 6 illustrates this variability in the pMn in comparison to $\mathrm{pAl}$ as a function of its location within the study area. The observed variability in $\mathrm{pMn}$ but not $\mathrm{pFe}$ relative to pAl highlights the uncoupling between some of the sources of $\mathrm{pMn}$ and $\mathrm{pFe}$. Specifically, the observed variability points to a uniquely high $\mathrm{Mn}: \mathrm{Fe}$ source either in the authigenic sediments of the Leclaire Rise and/or a hydrothermal source (German et al., 1991), or a process whereby pAl is preferentially stripped out with distance from the source. A study by Shigemitsu et al. (2013) showed that the concentration of $\mathrm{pAl}$ in suspended particulate material in the intermediate water of the Sea of Okhotsk (western Pacific Ocean) decreased with distance from the shelf source preferentially in relation to $\mathrm{pFe}$ and $\mathrm{pMn}$. They concluded that increasing $\mathrm{pFe}: \mathrm{pAl}$ and $\mathrm{pMn}: \mathrm{pAl}$ ratios occurred with distance from the source and suggested that the denser, lithogenic particles settled out preferentially, stripping out pAl. Furthermore, they found $\mathrm{pFe}$ became associated with organic matter more readily than $\mathrm{pAl}$ and therefore, remained suspended in the water column more readily than pAl. These processes could explain the observed modification of the elemental ratios between stations R-2, A3 and possibly F-L. The stations that were in close proximity to the shelf source such as A3-1 and A3-2 were indeed enriched in lithogenic $\mathrm{pAl}$ and as such $\mathrm{pFe}: \mathrm{pAl}$ was relatively low (Fig. 5). In contrast, F-L was at the greatest distance from a sedimentary source and displayed the highest $\mathrm{pFe}: \mathrm{pAl}$ ratio.

\subsection{What are the sources of particulate trace metals over the plateau and downstream?}

The high particulate trace metal concentrations found at $440 \mathrm{~m}$, at A3-1 and A3-2, near the sea floor, most likely originated from resuspension of deep $(\sim 500 \mathrm{~m})$ shelf sediments. The cause of the variability between A3-1 and A3-2 at this depth remains unclear, but could reflect small scale variability in the depth of the nepheloid layer or be the result of temporal variability due to the action of tides and internal waves (McCave, 1986). The $\mathrm{pMn}: \mathrm{pAl}, \mathrm{pMn}: \mathrm{pFe}$ and $\mathrm{pBa}: \mathrm{pAl}$ ratios for $\mathrm{A} 3-1$ and $\mathrm{A} 3-2$ are similar from the sea floor to the approximate base of the surface mixed layer, with values higher than the mean crustal ratios (Wedepohl, 1995), but lower than either basalt (Gautier et al., 1990) or the underlying sediment ratios (Table 2). Within the surface mixed layer, A3-1 maintains similar ratios to the deep water column, while at A3-2 the ratios diverge towards the surface. The particulate trace metal signature within the mixed layer at A3-2 increases in $\mathrm{pMn}$ and $\mathrm{pBa}$ relative to $\mathrm{pAl}$, which is most likely driven by biogenic conversion of dissolved bioessential elements into biogenic particles (Sect. 3.7).

Glacial flour is the result of mechanical erosion of bed rock by glaciers. Typical particle sizes are within the silt size range but can overlap with clays $(0.002-0.063 \mathrm{~mm})$. Recent research suggests that $\mathrm{Fe}$ sourced from glacial erosion can be a major source of bioavailable Fe to the Southern Ocean (Poulton and Raiswell, 2005; Raiswell et al., 2008a, b, 2006). Assuming no mixing and a dilute suspension, Stokes' law predicts that the small grain size of glacial flour allows it to remain suspended within a $500 \mathrm{~m}$ water column for between 2 and 2500 days or within a $165 \mathrm{~m}$ mixed layer for 1-831 days depending on particle size. Certainly, mixing within the surface mixed layer would increase this duration significantly, meaning that glacial and fluvial input from both Heard and Kerguelen Island could remain suspended in the mixed layer for long enough to travel well past any of the stations in the present study, excluding the reference station (R-2). Furthermore, it has been shown that $2-3 \%$ of the Fe within glacial rock flour can be leached into the dissolved size fraction $(<0.2 \mu \mathrm{m})$ with ultrapure water; a large proportion of which should be bioavailable (Schroth et al., 2009). It is thought that this $\mathrm{dFe}$ is leached from nanoparticulate $\mathrm{Fe}$ (oxyhydr)oxides in glacial rock flour over time (Raiswell, 2011; Raiswell et al., 2010) following an exponential decay, so it is possible that this source could be excluded from the $<0.2 \mu \mathrm{m}$ dissolved fraction, but included in the 1-53 $\mu \mathrm{m}$ particulate fraction presented here. This is especially true of nanoparticulate Fe that is attached to the surface of larger sediment grains as has been observed previously in glacial sediments (Shaw et al., 2011). Given that the particulate fraction is generally an order of magnitude higher in concentration than the dissolved fraction, this source may well be more significant in stimulating phytoplankton blooms than previously estimated. Overall, station A3 appeared to be directly fertilised by resuspension of shelf sediments at depth, and entrainment of this $\mathrm{pFe}$-rich water occurred during events that deepen the mixed layer periodically. However, lateral supply above the mixed layer of small particles from shallow coastal sources around Heard Island, including glacial melt waters, cannot be ruled out.

\subsection{Biogenic and sedimentary particulate trace metals}

If we assume that all particulate phosphorus (pP) is of biogenic origin, we can calculate the biogenic $\mathrm{Fe}$ fraction of the total $\mathrm{Fe}$ concentration by normalising to $\mathrm{pP}$ and comparing with published elemental ratios of Southern Ocean diatoms (Planquette et al., 2013). For the calculations we used the upper limit of $\mathrm{Fe}: \mathrm{P}\left(1.93 \mathrm{mmol} \mathrm{mol}^{-1}\right)$ reported by Twinning et al. (2004) for Southern Ocean diatom assemblages. Given that $\mathrm{pP}$ and POC are remineralised throughout the water column and are generated within the surface mixed layer, calculations of biogenic trace metals will only be valid within the surface mixed layer, as the concentration of pP and POC decreases strongly with depth. It should also be noted that Kerguelen Island basalts and upper continental crust can contribute particulate phosphorus concomitantly with $\mathrm{pFe}$ to the particulate pool. However the $\mathrm{Fe}$ : $\mathrm{P}$ ratio found within Kerguelen Island basalts and the continental crust is 12.8 and 25.8 (mol: $\mathrm{mol})$ respectively (Gautier et al., 
1990; Wedepohl, 1995). Thus, the factor of 1000 increase in pP observed within suspended particles compared to these rock sources indicates that this $\mathrm{pP}$ is likely produced in situ within the mixed layer from dissolved $\mathrm{PO}_{4}^{-}$rather than supplied from rock weathering together with Fe. Furthermore, within the upper $200 \mathrm{~m}$ of the water column, biogenic Fe correlates significantly with both fluorescence (Spearman's $\rho$ $R=0.518, P<0.05, n=30$ ) and dissolved oxygen (Spearman's $\rho R=0.507, P<0.05, n=30$ ) confirming the autotrophic composition of the particles identified as high in biogenic Fe. Figure 3 illustrates the contribution of biogenic $\mathrm{Fe}$ in surface waters at stations R-2, A3 and F-L. Station R2 and F-L have biogenic Fe fractions that are higher near the surface than at depth (Fig. 3). In contrast, at stations A3-1 and A3-2, biogenic Fe and Mn only make up a relatively small fraction of the total $\mathrm{pFe}$ throughout the water column although at station A3-2 we see a slight increase in biogenic $\mathrm{pFe}$ towards the surface, corresponding with the development of a bloom. Biogenic Fe at stations A3-1 and A32 constitutes less than 1 and $5 \%$ respectively of the total $\mathrm{Fe}$. The low biogenic fraction at station A3-1 most likely results from an excess of lithogenic $\mathrm{Fe}, \mathrm{Al}$ and $\mathrm{Mn}$ to the water column from the shelf sediments as well as fluvial/glacial runoff from nearby islands of the Kerguelen Archipelago, which are excess to demand. A similar pattern was observed during a study located in the Amundsen Sea (Planquette et al., 2013) where the percentage of biogenic Fe (full water column mean) reduced with proximity to the trace metal source.

Alternatively, the relative importance of sedimentary input at each of the stations can be gauged by observing the $\mathrm{pMn}$ : pAl molar ratio within suspended particles and comparing these to known molar ratios of $\mathrm{pMn}$ : $\mathrm{pAl}$ within Kerguelen Island basalts, A3 authigenic sediments and R-2 authigenic sediments (Fig. 6). At station A3 we see that almost all the suspended particles lie within the ratio of plateau sediments and Kerguelen Island basalts with the remaining suspended particles associated with the development of a bloom in surface waters at A3-2, which is also where we see an increase in biogenic Fe. Mid-depth suspended particles at E4W (red dots) also lie between Kerguelen Island basalts and plateau sediments, indicating a similar source to station A3. The reference station exhibits highly modified pMn : pAl molar ratios within the suspended particles and its underlying sediment. This modification is most likely due to biogenic incorporation of bioessential elements such as Mn into particles. The remaining stations are intermediate between A-3 and R-2.

\subsection{Pseudo-Lagrangian, recirculation structure}

Station E-4W has trace metal concentrations, elemental ratios and community size structure (Trull et al., 2014) similar to A3 and as such, will be excluded from the discussion in this section. The remaining recirculation structure stations exhibit profiles of $\mathrm{pFe}$ and $\mathrm{pMn}$ which show a minimum at approximately $150-175 \mathrm{~m}$ (Fig. 7). Our detailed depth profile indicates that the $\mathrm{pFe}$ and $\mathrm{pMn}$ minima coincide with the remnant winter water temperature minimum (Fig. 8). Interestingly, Blain et al. (2014) also estimated a winter water depth of approximately $150 \mathrm{~m}$. They observed, at $150 \mathrm{~m}$, that nitrate and phosphate profiles within the recirculation feature, from multiple years and seasons, converged with striking consistency. Particulate $\mathrm{Fe}$ and $\mathrm{pMn}$, concentrations increase above and below the temperature minimum, however, pAl only increases below $175 \mathrm{~m}$. Particulate $\mathrm{Al}$ is stripped out preferentially with settling lithogenics while $\mathrm{pFe}$ and $\mathrm{pMn}$ are retained either through conversion to the biogenic particulate fraction (uptake) or adsorbed onto organic particles. It should be noted here that the work of Raiswell (2011) indicates that iceberg and glacially derived $\mathrm{Fe}$ nanoparticulate material is typically high in Fe and low in Al. Thus, supply of glacially derived nanoparticulate $\mathrm{Fe}$ from Kerguelen Island, via the north-east of the recirculation structure could also cause the observed high $\mathrm{Fe}$, low $\mathrm{Al}$ surface enrichment within the recirculation structure.

Given that the $\mathrm{pFe}$ and $\mathrm{pMn}$ minima coincides with the remnant-winter-water temperature minimum, the total amount of particulate trace metals distributed throughout the winter mixed layer must be lower than during summer. This is counterintuitive if sediment resuspension is the primary source of particulate trace metals into the recirculation feature. During winter we would expect increased wind mixing, leading to more entrainment of $\mathrm{pFe}$ over the plateau and more supply into the recirculation feature leading to a maximum at the temperature minimum. Given that we observe the inverse situation, supply into the recirculation structure must be low during winter. Thus, we suggest that the lateral supply of fluvial and glacial derived particulate trace metals must be an important source. This source would be expected to reduce in winter when precipitation as snow and glacial freezing is at a maximum and conversely, during spring, snow and ice melt and rainfall increases runoff into the coastal areas and induces a fertilisation event downstream of Heard and Kerguelen Islands. Kerguelen Island is a subantarctic island, and its climatology is cold and wet, with the Port-aux-Français weather station recording mean daily temperatures of $2.1^{\circ} \mathrm{C}$ in winter and $8.2{ }^{\circ} \mathrm{C}$ in summer and year round consistent precipitation ( $730 \mathrm{~mm}$ annually) (Meteo France). It should be noted that due to its sheltered location and sea-level altitude, the Port-aux-Français location is relatively mild compared to the west coast and interior of the island which is estimated to receive three times the rainfall of the east coast, or $2124 \mathrm{~mm}$ annually. Therefore, having a climate of high precipitation and seasonal thawing, increased seasonal runoff can be expected in spring and summer from Kerguelen Island.

The importance of glacial/fluvial sources in supplying dissolved $\mathrm{Fe}$ and $\mathrm{Mn}$ into coastal waters to the north-east of Kerguelen, north of the PF, has been shown previously by Bucciarelli et al. (2001). The authors found a linear relationship between dissolved $\mathrm{Fe}$ and lithogenic silica and suggested 

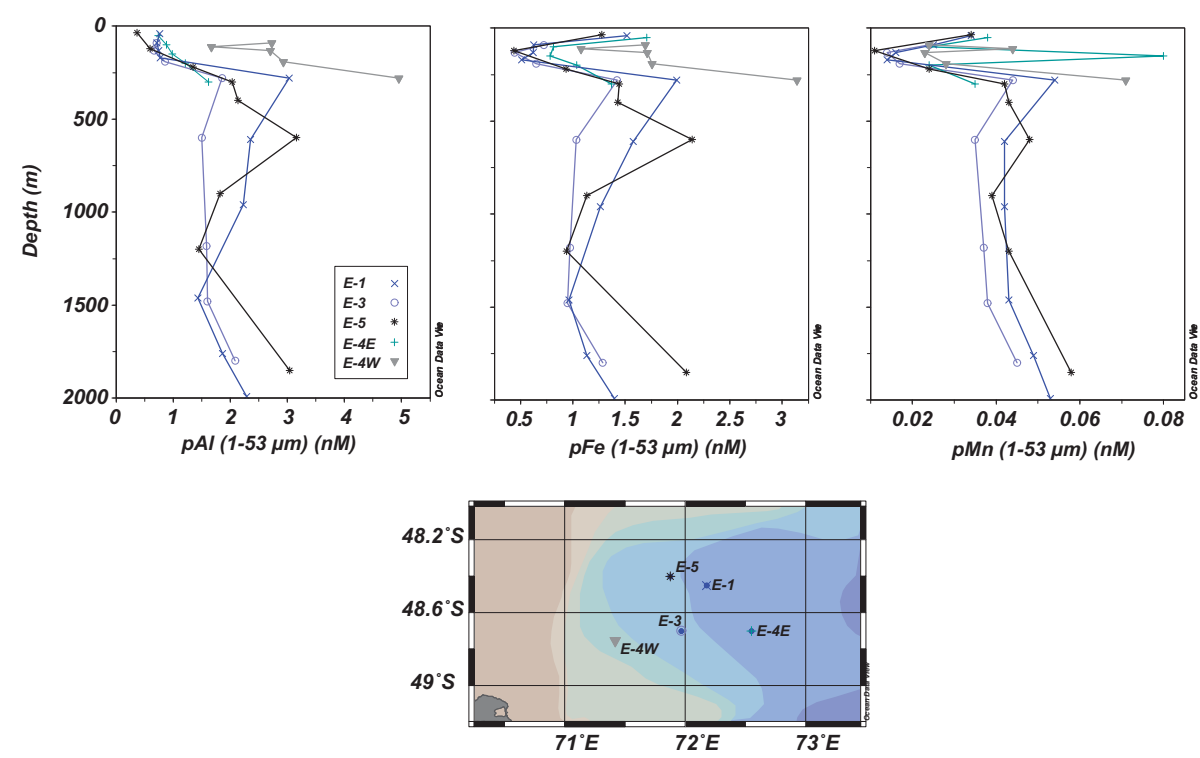

Figure 7. Profiles of particulate trace metals during the pseudo-Lagrangian recirculation-structure study. Station E-4W (gray triangle) exhibits unique trace metal profiles in comparison to the remaining stations (see text for details). Note the distinct $\mathrm{pFe}$ and $\mathrm{pMn}$ minima at $150-175 \mathrm{~m}$. Particulate Al exhibits a similar profile albeit without surface enrichment.
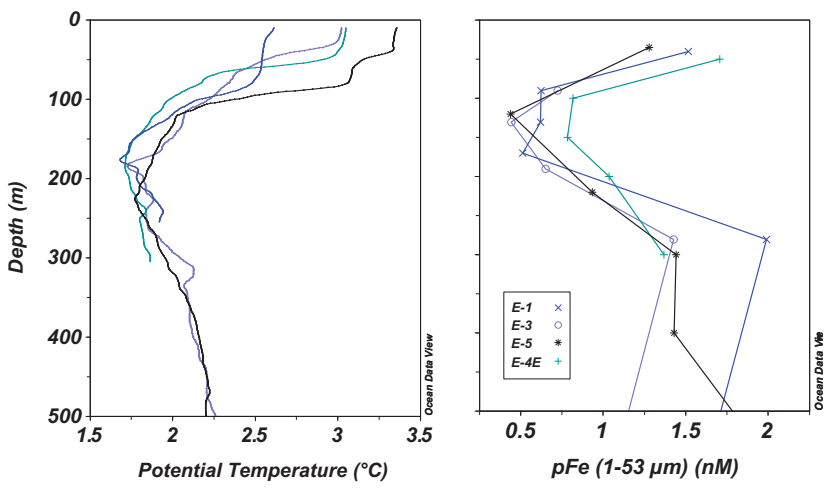

Figure 8. Temperature profiles within the upper $500 \mathrm{~m}$ within the recirculation structure are shown alongside particulate Fe $(1-53 \mu \mathrm{m})$ within the upper $500 \mathrm{~m}$ within the recirculation structure. Correspondence between the temperature minimum depth of winter water and $\mathrm{pFe}$ minimum is illustrated.

that this was indicative of weathering of silicate rich minerals that characterise the Kerguelen Islands with a concomitant release of dissolved $\mathrm{Fe}$ and $\mathrm{Mn}$. Indeed, in the present study, using the lithogenic and biogenic silica data presented in Closset et al. (2014), total particulate Fe correlated significantly with total lithogenic silica $(R=0.76, P<0.01)$ but not with biogenic silica. However, this significant correlation was not limited to the coastal regions in the present study and instead was observed for all stations and depths combined. Bucciarelli et al. (2001) found an exponential decrease in dissolved Fe with distance from the coast, further supporting their theory of a dominant coastal source in this region.
This exponential decrease would be expected to apply to the particulate fraction also; however, it appears that even with an exponential decrease in $\mathrm{pFe}$ with distance from the coast, particulate Fe enrichment, sourced from fluvial runoff, is evident on the southern side of the PF within the recirculation feature.

The hypothesis of pFe supply from north of the PF into the eastern side of the recirculation feature via the mixing zone is supported by radium isotope data (Sanial et al., 2014) collected during the KEOPS2 mission. Apparent radium ages derived from the ratio of ${ }^{224} \mathrm{Ra} /{ }^{223} \mathrm{Ra}$ (and using the ratio observed within the Baie des Baleiniers as the starting time) suggest that the age of water since fertilisation within the recirculation feature was only 5-8 days. This indicates that there is likely rapid transfer across the PF of fertilised waters which were sourced from nearby shallow coastal areas such as the Baie des Baleiniers, Kerguelen Island. The authors go on to highlight that the heterogeneous distribution of ${ }^{224} \mathrm{Ra}$ and ${ }^{223} \mathrm{Ra}$ indicates that transfer across the Polar Front is sporadic in nature.

The observation of $\mathrm{pFe}$ enrichment in surface waters of the recirculation structure without proportional concentrations of pAl may be due to biological uptake and conversion from a bioavailable pool into the biogenic particulate pool. Settling of refractory lithogenics that are high in $\mathrm{Al}$ may also partially explain the observation. Alternatively or in combination, a high $\mathrm{pFe}$, low pAl source such as nanoparticulate Fe characteristic of glacial/fluvial runoff (Hawkings et al., 2014; Raiswell et al., 2008b, 2006) on Kerguelen Island could explain this observation. Indeed, temperature and salinity profiles within the recirculation structure reveal 
fresher and warmer water within the upper $110 \mathrm{~m}$ than either the R-2 or A3 stations, suggesting that glacial/fluvial runoff from Kerguelen Island may well be delivering this high $\mathrm{pFe}$, low pAl surface enrichment.

\section{Conclusions}

This study has identified two distinct areas of Fe fertilisation in the vicinity of Kerguelen Island. Firstly, the plateau itself is a major source of resuspended shelf sediments to station A3 especially below the mixed layer. Secondly, fluvial and glacial runoff into coastal waters in combination with resuspension of shallow coastal sediments fertilises areas to the north of the PF, east of Kerguelen Island, but also across the $\mathrm{PF}$ and into the recirculation feature from the north-east. Indications of particle transport across the PF were observed at station R-2 sourced from the Leclaire Rise to the north of the PF. Satellite imagery also revealed filaments clearly diverging from the main jet of the PF and into the north east of the recirculation structure. Within the recirculation structure, the correspondence of the winter water temperature minimum with the particulate trace metal minimum implies that a seasonal cycle is involved in the supply of trace elements. This is most likely driven by increased fluvial and glacial runoff in summer, associated with rainfall and basal melt and reduced supply in winter when snowfall and freezing conditions predominate. In this complex region, it appears that weathering of the islands themselves are direct sources of new $\mathrm{Fe}$ and help stimulate the seasonal bloom that is significant in terms of the regional carbon cycle.
Over the mesoscale, it appears that physical processes associated with settling of refractory lithogenic particles was an important process in modifying the particulate elemental ratios. However, on the individual profile scale, biological processes seem important in modifying the elemental ratios in surface waters through preferential uptake of bio-essential elements, even from the particulate fraction.

Repeat sampling over the plateau provided a perspective on the persistence of the particulate $\mathrm{Fe}$ availability. Small particles containing $\mathrm{pFe}$ were efficiently transported out of the mixed layer during a bloom event over stations A3. This resulted in a $70 \%$ reduction in the integrated $\mathrm{pFe}$ stock within the mixed layer as a result of physical aggregation of small particles onto phyto-aggregates, presumably decreasing particle buoyancy and increasing export out of the mixed layer. This is likely to be an important aspect of the complex interaction between iron supply and biological availability, capable of mediating bloom duration and thus the efficiency of carbon sequestration. 
Appendix A: Certified reference material analysis

Table A1. Percentage recoveries of BCR-414 certified reference material. Certified and single lab values taken from the final report of the Commission of the European Communities, Community Bureau of Reference for BCR-414, EUR14558.

\begin{tabular}{lrrrrrrrrrr}
\hline $\mathrm{mg} \mathrm{kg}^{-1}$ & Rep 1 & Rep 2 & Rep 3 & Mean & SD & RSD (\%) & Certified & \% recovery & Single lab analysis & $\%$ recovery \\
\hline $\mathrm{Ba}$ & 34 & 26 & 32 & 31 & 4.0 & 13.1 & & & 31 & 99 \\
$\mathrm{Al}$ & 2243 & 1349 & 1943 & 1845 & 454.6 & 24.6 & & & 1800 & 102 \\
$\mathrm{Mn}$ & 278 & 284 & 283 & 282 & 3.4 & 1.2 & 299 & 94 & & \\
$\mathrm{Fe}$ & 1874 & 1850 & 1878 & 1867 & 15.0 & 0.8 & 1850 & 101 & \\
\hline
\end{tabular}


Acknowledgements. This work was supported by the Antarctic Climate and Ecosystems Cooperative Research Centre, University of Tasmania, Australia. This work was also supported by the French research program of INSU-CNRS LEFE-CYBER (Les enveloppes fluides et l'environnement - Cycles biogéochimiques, environnement et ressources), the French ANR (Agence Nationale de la Recherche, SIMI-6 program, ANR-10-BLAN-0614), the French CNES (Centre National d'Etudes Spatiales) and the French Polar Institute IPEV (Institut Polaire Paul-Emile Victor). We would like to thank the captain and the crew of the R/V Marion Dufresne, Stephane Blain and Bernard Quéguiner as chief scientist and project coordinator of the KEOPS 2 cruises, respectively. L. Armand was supported by grant Australian Antarctic Division, AAS grant \#3214. Access to Sector Field ICP-MS instrumentation was supported through ARC LIEF funding (LE0989539). F. Dehairs was supported by Belgian Science Policy grant SD/CA/05A; Flanders Research Foundation grant G071512N and Vrije Universiteit Brussel, Strategic Research Plan.

Edited by: I. Obernosterer

\section{References}

Angino, E.: Geochemistry of Antarctic pelagic sediments, Geochim. Cosmochim. Ac., 30, 939-961, 1966.

Angino, E. and Andrews, R.: Trace element chemistry, heavy minerals, and sediment statistics of Weddell Sea sediments, J. Sediment. Res., 38, 634-642, 1968.

Armand, L. K., Crosta, X., Quéguiner, B., Mosseri, J., and Garcia, N.: Diatoms preserved in surface sediments of the northeastern Kerguelen Plateau, Deep-Sea Res.-Pt. II, 55, 677-692, 2008.

Barnola, J. M., Raynaud, D., Korotkevich, Y. S., and Lorius, C.: Vostok ice core provides 160000-year record of atmospheric $\mathrm{CO}_{2}$, Nature, 329, 408-414, 1987.

Blain, S., Queguiner, B., Armand, L., Belviso, S., Bombled, B., Bopp, L., Bowie, A. R., Brunet, C., Brussaard, C., Carlotti, F., Christaki, U., Corbiere, A., Durand, I., Ebersbach, F., Fuda, J. L., Garcia, N., Gerringa, L., Griffiths, B., Guigue, C., Guillerm, C., Jacquet, S. H. M., Jeandel, C., Laan, P., Lefevre, D., Lo Monaco, C., Malits, A., Mosseri, J., Obernosterer, I., Park, Y. H., Picheral, M., Pondaven, P., Remenyi, T., Sandroni, V., Sarthou, G., Savoye, N., Scouarnec, L., Souhaut, M., Thuiller, D., Timmermans, K., Trull, T., Uitz, J., Van Beek, P., Veldhuis, M., Vincent, D., Viollier, E., Vong, L., and Wagener, T.: Effect of natural iron fertilization on carbon sequestration in the Southern Ocean, Nature, 446, 1070-1074, 2007.

Blain, S., Capparos, J., Guéneuguès, A., Obernosterer, I., and Oriol, L.: Distributions and stoichiometry of dissolved nitrogen and phosphorus in the iron fertilized region near Kerguelen (Southern Ocean), Biogeosciences Discuss., 11, 9949-9977, doi::10.5194/bgd-11-9949-2014, 2014.

Bopp, L., Kohfeld, K. E., Le Quéré, C., and Aumont, O.: Dust impact on marine biota and atmospheric $\mathrm{CO}_{2}$ during glacial periods, Paleoceanography, 18, 1-24, 2003.

Bowie, A. R., Townsend, A. T., Lannuzel, D., Remenyi, T. A., and van der Merwe, P.: Modern sampling and analytical methods for the determination of trace elements in marine particulate material using magnetic sector inductively coupled plasma-mass spectrometry, Anal. Chim. Acta, 676, 15-27, 2010.

Bowie, A. R., van der Merwe, P., Quéroué, F., Trull, T., Fourquez, M., Planchon, F., Sarthou, G., Chever, F., Townsend, A. T., Obernosterer, I., Sallée, J.-B., and Blain, S.: Iron budgets for three distinct biogeochemical sites around the Kerguelen archipelago (Southern Ocean) during the natural fertilisation experiment KEOPS-2, Biogeosciences Discuss., 11, 17861-17923, doi:10.5194/bgd-11-17861-2014, 2014.

Boyd, P. W., Jickells, T., Law, C. S., Blain, S., Boyle, E. A., Buesseler, K. O., Coale, K. H., Cullen, J. J., de Baar, H. J. W., Follows, M., Harvey, M., Lancelot, C., Levasseur, M., Owens, N. P. J., Pollard, R., Rivkin, R. B., Sarmiento, J., Schoemann, V., Smetacek, V., Takeda, S., Tsuda, A., Turner, S., Watson, A. J., and Baar, H. J. W. De: Mesoscale iron enrichment experiments 1993-2005: Synthesis and future directions, Science, 315, 612-617, 2007.

Bucciarelli, E., Bowie, A. R., and Tréguer, P.: Iron and manganese in the wake of the Kerguelen Islands (Southern Ocean), Mar. Chem., 73, 21-36, 2001.

Chever, F., Sarthou, G., Bucciarelli, E., Blain, S., and Bowie, A. R.: An iron budget during the natural iron fertilisation experiment KEOPS (Kerguelen Islands, Southern Ocean), Biogeosciences, 7, 455-468, doi:10.5194/bg-7-455-2010, 2010.

Closset, I., Lasbleiz, M., Leblanc, K., Quéguiner, B., Cavagna, A.J., Elskens, M., Navez, J., and Cardinal, D.: Seasonal evolution of net and regenerated silica production around a natural $\mathrm{Fe}$ fertilized area in the Southern Ocean estimated with Si isotopic approaches, Biogeosciences, 11, 5827-5846, doi:10.5194/bg-115827-2014, 2014.

Cullen, J. T. and Sherrell, R. M.: Techniques for determination of trace metals in small samples of size-fractionated particulate matter: Phytoplankton metals off central California, Mar. Chem., 67, 233-247, 1999.

Cutter, G., Andersson, P., Codispoti, L., Croot, P., Francois, R., Lohan, M., Obata, H., and Rutgers van der Loeff, M.: Sampling and Sample-handling Protocols for GEOTRACES Cruises, http://www.geotraces.org/images/stories/documents/ intercalibration/Cookbook.pdf, 2010.

De Baar, H. J. W., Boyd, P. W., Coale, K. H., Landry, M. R., Tsuda, A., Assmy, P., Bakker, D. C. E., Bozec, Y., Barber, R. T., Brzezinski, M. A., Buesseler, K. O., Boye, M., Croot, P. L., Gervais, F., Gorbunov, M., Harrison, P. J., Hiscock, W. T., Laan, P., Lancelot, C., Law, C. S., Levasseur, M., Marchetti, A., Millero, F. J., Nishioka, J., Nojiri, Y., van Oijen, T., Riebesell, U., Rijkenberg, M. J. A., Saito, H., Takeda, S., Timmermans, K. R., Veldhuis, M. J. W., Waite, A., and Wong, C.-S.: Synthesis of iron fertilization experiments: From the Iron Age in the Age of Enlightenment, J. Geophys. Res., 110, C09S16, doi:10.1029/2004JC002601, 2005.

De Baar, H. J. W. and de Jong, J. T.: Distribution, sources and sinks of iron in seawater, edited by: Turner, D. R. and Hunter, K. A., in: The Biogeochemistry of Iron in Seawater, IUPAC Series on Analytical and Physical Chemistry of Environmental Systems, 123-253, 2001.

Doucet, S., Scoates, J. S., Weis, D., and Giret, A.: Constraining the components of the Kerguelen mantle plume: A Hf- $\mathrm{Pb}-\mathrm{Sr}-\mathrm{Nd}$ isotopic study of picrites and high- $\mathrm{MgO}$ basalts from the Kerguelen Archipelago, Geochem. Geophys. Geosys., 6, 1-28, 2005.

Frew, R. D., Hutchins, D. A., Nodder, S., Sanudo-Wilhelmy, S., Tovar-Sanchez, A., Leblanc, K., Hare, C. E., and Boyd, P. W.: 
Particulate iron dynamics during FeCycle in subantarctic waters south-east of New Zealand, Global Biogeochem. Cy., 20, GB1S93, 2006.

Gautier, I., Weis, D., Mennessier, J.-P., Vidal, P., Giret, A., and Loubet, M.: Petrology and geochemistry of the Kerguelen Archipelago basalts (South Indian Ocean) evolution of the mantle sources from ridge to intraplate position, Earth Planet. Sci. Lett., 100, 59-76, 1990.

German, C., Campbell, A., and Edmond, J.: Hydrothermal scavenging at the Mid-Atlantic Ridge: modification of trace element dissolved fluxes, Earth Planet. Sci. Lett., 107, 101-114, 1991.

Hawkings, J. R., Wadham, J. L., Tranter, M., Raiswell, R., Benning, L. G., Statham, P. J., Tedstone, A., Nienow, P., Lee, K., and Telling, J.: Ice sheets as a significant source of highly reactive nanoparticulate iron to the oceans, Nat. Commun., 5, 3929, 2014.

Johnson, K. S., Gordon, R. M., and Coale, K. H.: What controls dissolved iron concentrations in the world ocean?, Mar. Chem., 57, 137-161, 1997.

Jouandet, M.-P., Jackson, G. A., Carlotti, F., Picheral, M., Stemmann, L., and Blain, S.: Rapid formation of large aggregates during the spring bloom of Kerguelen Island: observations and model comparisons, Biogeosciences, 11, 4393-4406, doi:10.5194/bg-11-4393-2014, 2014.

Lasbleiz, M., Leblanc, K., Blain, S., Ras, J., Cornet-Barthaux, V., Hélias Nunige, S., and Quéguiner, B.: Pigments, elemental composition $(\mathrm{C}, \mathrm{N}, \mathrm{P}$, and $\mathrm{Si})$, and stoichiometry of particulate matter in the naturally iron fertilized region of Kerguelen in the Southern Ocean, Biogeosciences, 11, 5931-5955, doi:10.5194/bg-115931-2014, 2014.

Laurenceau, E. C., Trull, T. W., Davies, D. M., Bray, S. G., Doran, J., Planchon, F., Carlotti, F., Jouandet, M.-P., Cavagna, A.J., Waite, A. M., and Blain, S.: The relative importance of phytoplankton aggregates and zooplankton fecal pellets to carbon export: insights from free-drifting sediment trap deployments in naturally iron-fertilised waters near the Kerguelen plateau, Biogeosciences Discuss., 11, 13623-13673, doi:10.5194/bgd11-13623-2014, 2014.

Martin, J. H.: Glacial-interglacial $\mathrm{CO}_{2}$ change: The iron hypothesis. Paleoceanography, 5, 1-13, 1990.

McCave, I. N.: Local and global aspects of the bottom nepheloid layers in the world ocean, Neth. J. Sea Res., 20, 167-181, 1986.

Moffett, J. W.: Transformations Among Different Forms of Iron in the Ocean, edited by: Turner, D. R. and Hunter, K. A., in: The Biogeochemistry of Iron in Seawater, John Wiley \& Sons, 343372, 2001.

Park, Y.-H., Roquet, F., Durand, I., and Fuda, J.-L.: Large-scale circulation over and around the Northern Kerguelen Plateau, DeepSea Res.-Pt. II, 55, 566-581, 2008.

Planchon, F., Ballas, D., Cavagna, A.-J., Bowie, A. R., Davies, D., Trull, T., Laurenceau, E., Van Der Merwe, P., and Dehairs, F.: Carbon export in the naturally iron-fertilized Kerguelen area of the Southern Ocean based on the ${ }^{234} \mathrm{Th}$ approach, Biogeosciences Discuss., 11, 15991-16032, doi:10.5194/bgd11-15991-2014, 2014.

Planquette, H., Sherrell, R. M., Stammerjohn, S., and Field, M. P.: Particulate iron delivery to the water column of the Amundsen Sea, Antarctica, Mar. Chem., 153, 15-30, 2013.
Pollard, R., Salter, I., Sanders, R., and Lucas, M.: Southern Ocean deep-water carbon export enhanced by natural iron fertilization, Nature, 457, 577-581, 2009.

Poulton, S. W. and Raiswell, R.: Chemical and physical characteristics of iron oxides in riverine and glacial meltwater sediments, Chem. Geol., 218, 203-221, 2005.

Quéguiner, B.: Iron fertilization and the structure of planktonic communities in high nutrient regions of the Southern Ocean, Deep-Sea Res.-Pt. II, 90, 43-54, 2013.

Quéroué, F., Sarthou, G., Planquette, H. F., Bucciarelli, E., Chever, F., van der Merwe, P., Lannuzel, D., Townsend, A. T., Cheize, M., Blain, S., d'Ovidio, F., and Bowie, A. R.: High variability of dissolved iron concentrations in the vicinity of Kerguelen Island (Southern Ocean), Biogeosciences Discuss., 12, 231-270, doi:10.5194/bgd-12-231-2015, 2015.

Raiswell, R.: Iceberg-hosted nanoparticulate Fe in the Southern Ocean: Mineralogy, origin, dissolution kinetics and source of bioavailable Fe, Deep-Sea Res.-Pt. II, 58, 1364-1375, 2011.

Raiswell, R., Tranter, M., Benning, L. G., Siegert, M., Death, R., Huybrechts, P., Payne, T., and Death, R.: Contributions from glacially derived sediment to the global iron (oxyhydr)oxide cycle: Implications for iron delivery to the oceans, Geochim. Cosmochim. Ac., 70, 2765-2780, 2006.

Raiswell, R., Benning, L. G., Tranter, M., and Tulaczyk, S.: Bioavailable iron in the Southern Ocean: The significance of the iceberg conveyor belt, Geochem. Trans., 9, doi:10.1186/14674866-9-7, 2008a.

Raiswell, R., Benning, L. G. L., Davidson, L., and Tranter, M.: Nanoparticulate bioavailable iron minerals in icebergs and glaciers, Mineral. Mag., 72, 345-348, 2008b.

Raiswell, R., Vu, H. P., Brinza, L., and Benning, L. G.: The determination of labile Fe in ferrihydrite by ascorbic acid extraction: Methodology, dissolution kinetics and loss of solubility with age and de-watering, Chem. Geol., 278, 70-79, 2010.

Sanial, V., van Beek, P., Lansard, B., Souhaut, M., Kestenare, E., d'Ovidio, F., Zhou, M., and Blain, S.: Use of Ra isotopes to deduce rapid transfer of sediment-derived inputs off Kerguelen, Biogeosciences Discuss., 11, 14023-14061, doi:10.5194/bgd11-14023-2014, 2014.

Savoye, N., Trull, T., Jacquet, S. H. M., Navez, J., and Dehairs, F.: ${ }^{234}$ Th-based export fluxes during a natural iron fertilization experiment in the Southern Ocean (KEOPS)- Deep-Sea Res.-Pt. II- 55, 841-855, 2008.

Schroth, A. W., Crusius, J., Sholkovitz, E. R., and Bostick, B. C.: Iron solubility driven by speciation in dust sources to the ocean, Nat. Geosci., 2, 337-340, 2009.

Shaw, T. J., Raiswell, R., Hexel, C. R., Vu, H. P., Moore, W. S., Dudgeon, R., and Smith, K. L.: Input, composition, and potential impact of terrigenous material from free-drifting icebergs in the Weddell Sea, Deep-Sea Res.-Pt. II, 58, 1376-1383, 2011.

Shigemitsu, M., Nishioka, J., Watanabe, Y. W., Yamanaka, Y., Nakatsuka, T., and Volkov, Y. N.: Fe/Al ratios of suspended particulate matter from intermediate water in the Okhotsk Sea: Implications for long-distance lateral transport of particulate $\mathrm{Fe}$, Mar. Chem., 157, 41-48, 2013.

Sunda, W. G.: Bioavailability and Bioaccumulation of Iron in the Sea, edited by: Turner, D. R. and Hunter, K. H., in: The Biogeochemistry of Iron in Seawater, IUPAC Series on Analytical and Physical Chemistry of Environmental Systems, 41-84, 2001. 
Taylor, S. R., McLennan, S. M., and Scott, M.: The continental crust, its composition and evolution?: an examination of the geochemical record preserved in sedimentary rocks, edited by: Taylor, S. R. and McLennan, S. M., Oxford, Melbourne: Blackwell Scientific Publications, 45-49, 1985.

Townsend, A. T.: The accurate determination of the first row transition metals in water, urine, plant, tissue and rock samples by sector field ICP-MS, J. Anal. At. Spectrom., 15, 307-314, 2000.

Trull, T. W., Davies, D. M., Dehairs, F., Cavagna, A.-J., Lasbleiz, M., Laurenceau, E. C., d'Ovidio, F., Planchon, F., Leblanc, K., Quéguiner, B., and Blain, S.: Chemometric perspectives on plankton community responses to natural iron fertilization over and downstream of the Kerguelen Plateau in the Southern Ocean, Biogeosciences Discuss., 11, 13841-13903, doi:10.5194/bgd11-13841-2014, 2014.
Twining, B. S., Baines, S. B., and Fisher, N. S.: Element stoichiometries of individual plankton cells collected during the Southern Ocean Iron Experiment (SOFeX), Limnol. Oceanogr., 49, 21152128, 2004.

Van Beek, P., Bourquin, M., Reyss, J. L., Souhaut, M., Charette, M. A., and Jeandel, C.: Radium isotopes to investigate the water mass pathways on the Kerguelen Plateau (Southern Ocean), Deep-Sea Res.-Pt. II, 55, 622-637, 2008.

Watson, A. J., Bakker, D. C. E., Ridgwell, A. J., Boyd, P. W., and Law, C. S.: Effect of iron supply on Southern Ocean $\mathrm{CO}_{2}$ uptake and implications for 407, 730-733, 2000.

Wedepohl, K. H.: The composition of the continental crust, Geochim. Cosmochim. Ac., 59, 1217-1232, 1995.

Zhang, Y., Lacan, F., and Jeandel, C.: Dissolved rare earth elements tracing lithogenic inputs over the Kerguelen Plateau (Southern Ocean), Deep-Sea Res.-Pt. II, 55, 638-652, 2008. 